\title{
PENGARUH STRUKTUR MODAL DAN PROFITABILITAS TERHADAP KEBIJAKAN DIVIDEN
}

\author{
${ }^{1}$ Indah Anggraeni Paramitha \\ ${ }^{2}$ Lisdawati, S.E., M.M. \\ Program Studi Manajemen, Fakultas Ekonomi, Universitas Pamulang \\ Email: indah814@gmail.com ${ }^{1}$, dosen02115@unpam.ac.id ${ }^{2}$
}

\begin{abstract}
ABSTRAK
Tujuan dari penelitian ini adalah untuk mengetahui dan memberi bukti empiris atas pengaruh Struktur Modal dan Profitabilitas baik secara parsial maupun simultan terhadap Kebijakan Dividen pada PT. Mayora Indah, Tbk periode 2011-2017. Struktur Modal menggunakan pengukuran debt-to Equity Ratio (DER), Profitabilitas menggunakan pengukuran Return On Asset (ROA) dan Kebijakan Dividen menggunakan pengukuran dividend payout ratio (DPR). Metode penelitian menggunakan data sekunder berupa laporan keuangan PT. Mayora Indah, Tbk serta analisis data menggunakan regresi linier berganda, pengujian asumsi klasik yang meliputi: Uji Normalitas, Multikolinearitas, Heteroskedastisitas serta Uji Autokorelasi, dan Uji Hipotesis. Hasil penelitian menunjukkan bahwa Struktur Modal dan Profitabilitas berpengaruh secara parsial dan simultan terhadap Kebijakan Dividen.
\end{abstract}

Kata kunci: kebijakan dividen, profitabilitas, struktur modal.

\begin{abstract}
The purpose of this study was to find out and give empirical study thru the effect of Capital Structure and Profitability in la partially and simultaneously on the Dividend Policy at PT. Mayora Indah, Tbk for the period 2011-2017. Capital Structure uses debt-to Equity Ratio (DER) metering, profitability uses Return On Asset (ROA) metering and Dividend Policy uses dividend payout ratio (DPR) metering. The research method uses secondary data in the form of financial statements of PT. Mayora Indah, Tbk and data analysis using multiple linear regression, classic assumptions test which include the normality, multicollinearity, heteroscedasticity and Autocorrelation tests, with hypothesis tests. The results showed that the Capital Structure and Profitability have a partial and simultaneous effect on the Dividend Policy.
\end{abstract}

Keywords: dividend policy, profitabilty, capital structure.

\section{PENDAHULUAN}

Perkembangan ekonomi suatu negara dapat diukur dengan berbagai cara, salah satunya yaitu dengan mengetahui tingkat perkembangan pasar modal (capital market) dan perkembangan berbagai jenis industri pada suatu negara. Menurut UU No 8 Tahun 1995 tentang pasar modal menyatakan bahwa, pasar modal Indonesia memiliki peran strategis dalam pembangunan nasional sebagai salah satu sumber pembiayaan bagi dunia usaha dan wahana investasi bagi masyarakat (Nasution, 2015). Aktivitas pasar modal, para investor memiliki tujuan investasi 
sumber dana perusahaan untuk mencari laba atau tingkat pengembalian investasi (return) baik berupa pendapatan dividen (dividen yield) maupun pendapatan dari selisih harga jual saham terhadap harga belinya (capital gain).

Besarnya pendapatan dividen yang dibagikan tergantung pada besarnya laba yang diperoleh dan kebijakan dividen yang ditetapkan oleh perusahaan. Kebijakan dividen adalah bagian yang tidak terpisahkan dalam keputusan pendanaan perusahaan (Horne \& Wachowicz, 2012). Perusahaan memiliki peran dalam menentukan berapa laba yang akan dibagikan kepada investor dan besarnya laba yang akan ditahan oleh perusahaan. Kebijakan dividen diproksikan dengan dividend payout ratio, yaitu persentase laba yang dibagikan dalam bentuk dividen tunai, artinya penentuan pembagian dividenakan mempengaruhi keputusan investasi investor dan di sisi lain berpengaruh pada kondisi keuangan perusahaan. Semakin besar dividen yang dibagikan oleh perusahaan maka akan semakin menarik bagi calon investor (Trisna Dewi \& Panji Sedana, 2014). Pembagian dividen akan memenuhi harapan investor untuk mendapatkan tingkat pengembalian (return) sebagai hasil dari investasi.

Kebijakan dividen merupakan kebijakan yang berperan penting dalam suatu perusahaan. Kebijakan dividen memiliki dampak penting bagi pihak-pihak yang terlibat didalamnya seperti perusahaan, pemegang saham dan kreditur. Faktor-faktor yang mungkin dapat mempengaruhi kebijakan dividen antara lain struktur modal yang diproksikan dengan debt to equity ratio (DER) dan profitabilitas yang diproksikan dengan return on asset (ROA).

Struktur Modal adalah perbandingan atau imbangan pendanaan jangka panjang perusahaan yang di tujukan oleh perbandingan hutang jangka panjang terhadap modal sendiri (Martono \& Harjito, 2010). Strukur modal berkaitan dengan jumlah hutang dan modal sendiri yang digunakan untuk membiayai aktiva perusahaan. Stuktur modal yang efektif mampu menciptakan perusahaan dengan keuangan yang kuat dan stabil. Bersamaan dengan meningkatnya pengetahuan masyarakat di bidang pasar modal dan tersedianya dana dari para calon investor yang berminat menginvestasikan modalnya, struktur modal telah menjadi salah satu faktor pertimbangan yang cukup penting hal ini terkait dengan resiko dan pendapatan yang akan diterima.

Struktur modal perusahaan dapat dilihat tanpa melepaskan fungsi investor dari informasi perusahaan berupa laporan keuangan yang dikeluarkan setiap tahunnya. Para investor akan melakukan berbagai analisis terkait dengan keputusan untuk menanamkan modalnya pada perusahan melalui informasi yang salah satunya berasal dari laporan keuangan perusahaan. Tujuan perusahaan adalah untuk memperoleh hasil penjualan yang maksimal dan jumlah aktiva yang optimal dalam menjalankan perusahaan. Besarnya aset perusahaan sangat 
menentukan besarnya perusahaan. Perusahaan menginginkan jumlah laba bersih sesudah dikurangi faktor pajak yang besar karena akan menambah jumlah modal yang akan di gunakan untuk usaha. Agar di peroleh laba yang besar, maka perusahaan akan mengupayakan untuk melakukan perencanaan pemasaran yang optimal dan efektif (Murtini, 2018).

Tujuan akhir yang ingin dicapai suatu perusahaan yang terpenting adalah memperoleh laba atau keuntungan yang maksimal, disamping hal-hal lainnya. Untuk mengukur tingkat keuntungan suatu perusahaan, digunakan rasio keuntungan atau rasio pfofitabilitas. Kemampuan laba perusahaan dapat disebut juga dengan profitabilitas yang digunakan untuk mengetahui kemampuan perusahaan dalam menghasilkan laba atau seberapa efektif pengelolaan perusahaan oleh manajemen (Kasmir, 2016, p.126).

Pada dasarnya perusahaan untuk memperoleh laba dan menjaga kontinuitas usaha guna mempertahankan kelangsungan hidup perusahaan serta mengembangkannya dimasa yang akan datang. Usaha dalam memajukan perusahaan, seorang manajer dituntut harus mampu mangarahkan sedemikian rupa agar tujuan yang akan di capai perusahaan dapat terwujud khususnya dalam hal peningkatan profitabilitasnya (Ginting \& Tarihoran, 2017).

Tabel 1 Data Rasio DER, ROA dan DPR Pada PT. Mayora Indah, Tbk Periode 2011-2017

\begin{tabular}{cccc}
\hline $\begin{array}{c}\text { Variabel } \\
\text { Tahun }\end{array}$ & $\begin{array}{c}\text { DER } \\
(\boldsymbol{\%})\end{array}$ & $\begin{array}{c}\text { ROA } \\
(\boldsymbol{\%})\end{array}$ & $\begin{array}{c}\text { DPR } \\
(\boldsymbol{\%})\end{array}$ \\
\hline 2011 & 1,72 & 7,33 & 20,60 \\
2012 & 1,71 & 8,95 & 13,42 \\
2013 & 1,47 & 10,85 & 17,34 \\
2014 & 1,50 & 4,01 & 49,88 \\
2015 & 1,18 & 11,17 & 11,77 \\
2016 & 1,06 & 10,41 & 20,43 \\
2017 & 1,02 & 10,53 & 29,90 \\
\hline
\end{tabular}

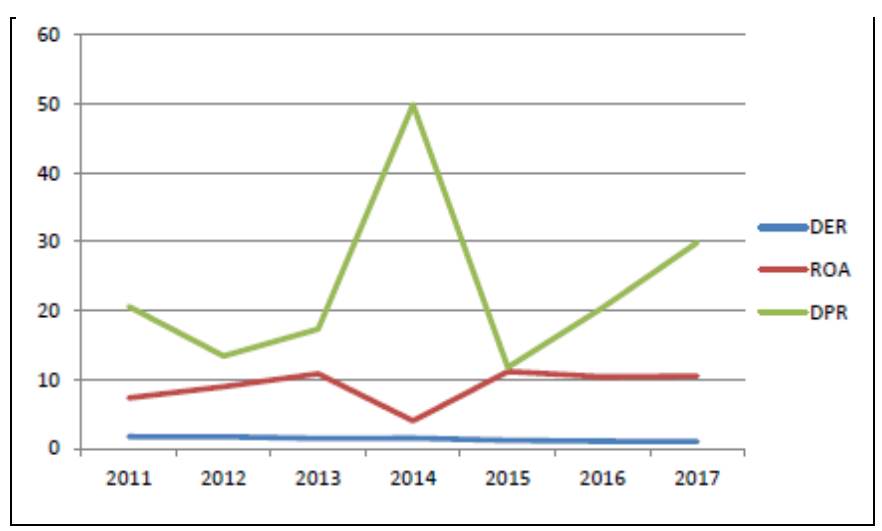

Gambar 1 Data Rasio DER, ROA dan DPR 
Berdasarkan Grafik 1.1 menunjukkan data rasio bersifat Fluktuatif. Adapun DER pada tahun 2011 memiliki nilai paling tinggi sebesar $1.72 \%$ dan nilai ROA pada tahun 2015 memiliki nilai paling tinggi sebesar 11,7\% dan nilai DPR pada tahun 2014 memiliki nilai paling tinggi sebesar 49,88\%. Data ini tentunya menjadi menarik untuk diteliti secara ilmiah mengingat pada tahun Rasio ROA dan DPR berhubungan dengan tidak searah.

Perusahaan harus dapat memenuhi kebutuhan operasional perusahaan dalam mempertahankan kelangsungan hidup dan mengembangkan perusahaan. Dalam hal ini perusahaan dituntut untuk dapat menghasilkan produk yang dapat memuaskan konsumen dan mengelola perusahaan dengan baik. Kesulitan manajer keuangan dalam menentukan keputusan pendanaan. Keputusan pendanaan berpengaruh terhadap profitabilitas dan risiko yang ditanggung pemegang saham serta besarnya tingkat pengembalian yang diharapkan untuk dapat mencapai keuntungan optimal bagi PT. Mayora Indah, Tbk. Berdasarkan hal di atas, maka penelitian ini bertujuan untuk mengetahui dan memberi bukti empiris pengaruh struktur modal, profitabilitas berpengaruh terhadap kebijakan dividen baik secara parsial maupun simultan.

Manajamen Keuangan menurut James C. Van Horne adalah adalah segala aktifitas yang berhubungan dengan perolehan, pendanaan, dan pengelolaan aktiva dengan beberapa tujuan menyeluruh (Kasmir, 2016, p.22). Selanjutnya, dalam rangka memaksimalkan pencapaian tujuan perusahaan, semua pihak yang terlibat dalam organisasi baik departemen produksi, keuangan, pemasaran maupun sumber daya manusia harus bekerja sama (Kasmir, 2016, p.13)sehingga tujuan manajemen keuangan melalui 2 (dua) pendekatan, yaitu profit risk approach dimana manajer keuangan tidak hanya sekedar mengajar maksimalisasi profit akan tetapi juga harus mempertimbangkan resiko yang bakal dihadapi besar serta liquidity and profitability merupakan kegiatan yang berhubungan dengan bagaimana seorang manajer mengelola likuiditas dan profitabilitas perusahaan, dimana dalam hal likuiditas manajer keuangan harus sanggup untuk menyediakan dana (uang kas) untuk membayar kewajiban yang sudah jatuh tempo secara tepat waktu.

Laporan keuangan itu sendiri merupakan kewajiban setiap perusahaan untuk membuat dan melaporkannya pada suatu periode tertentu. Laporan keuangan juga akan menentukan langkah apa yang dilakukan perusahaan sekarang dan kedepan, dengan melihat berbagai persoalan yang ada, baik kelemahan maupun kekuatan yang dimiliki (Kasmir, 2016, p.66). Analisa laporan keuangan dilakukan dengan tujuan sebagai berikut: (1) screening dimana analisa bertujuan untuk mengetahui situasi dan kondisi perusahaan dari laporan keuangan tanpa pergi langsung ke lapangan; (2) understanding dilakukan dengan tujuan untuk 
memahami perusahaan, kondisi keuangan dan hasil usahanya; (3) forecasting dimana analisa dilakukan untuk meramalkan kondisi keuangan perusahaan dimasa yang akan datang; (4) diagnosis dimana analisa dimaksudkan untuk melihat kemungkinan adanya masalah-masalah yang terjadi baik dalam manajemen, operasi keuangan atau masalah lain dalam perusahaan; dan (5) evaluation dimana analisa dilakukan untuk menilai prestasi manajemen dalam mengelola perusahaan (Harahap, 2009, p.18).

Struktur modal (capital structure) adalah perbandingan atau imbangan pendanaan jangka panjang yang ditujukan oleh perbandingan hutang jangka panjang terhadap modal sendiri. Pendanaan yang efisien akan terjadi bila perusahaan mempunyai struktur modal yang optimal. Struktur modal yang optimal dapat diartikan sebagai struktur modal yang dapat meminimalkan biaya penggunaan modal keseluruhan atau biaya modal rata-rata sehingga akan memaksimalkan nilai perusahaan (Martono \& Harjito, 2010). Keputusan struktur modal berkaitan dengan pemilihan sumber dana baik yang berasal dari dalam maupun dari luar sangat mempengaruhi nilai perusahaan. Sumber dana perusahaan dari internal berasal dari laba ditahan dan depresiasi. Dana yang diperoleh dari sumber eksternal adalah dana yang berasal dari para kreditur dan pemilik perusahaan. Pemenuhan kebutuhan dana yang berasal dari kreditur merupakan hutang bagi perusahaan. Dana yang diperoleh dari pemilik merupakan modal sendiri. Penelitian ini menggunakan proksi Debt-to Equity Ratio untuk mengukur struktur modal.

Profitabilitas merupakan faktor yang seharusnya mendapat perhatian penting karena untuk dapat melangsungkan hidupnya, suatu perusahaan harus berada dalam keadaan yang menguntungkan (profitable). Tanpa adanya keuntungan (profit) maka akan sangat sulit bagi perusahaan untuk menarik modal dari luar. Para kreditur, pemilik perusahaan, dan terutama sekali dari pihak manajemen perusahaan akan berusaha meningkatkan keuntungan karena disadari benar betapa pentingnya arti dari profit terhadap kelangsungan dan masa depan perusahaan (Rahayu \& Sari, 2018). profitabilitas terdiri atas dua jenis yaitu rasio yang menunjukkan profitabilitas dalam kaitannya dengan penjualan dan rasio yang menunjukkan profitabilitas dalam kaitannya dengan investasi. Profitabilitas dalam hubungannya dengan penjualan terdiri atas margin laba kotor (gross profit margin) dan margin laba bersih (net profit margin). Profitabilitas dalam hubungannya dengan investasi terdiri atas tingkat pengembalian atas aktiva (return on total asset) dan tingkat pengembalian atas ekuitas (return on equity). 
Tabel 2 Kriteria Peringkat Komponen ROA

\begin{tabular}{ccc}
\hline Rasio & Peringkat & Predikat \\
\hline ROA $>1,5 \%$ & 1 & Sangat Baik \\
$1,25 \%<$ ROA $\leq 1,5 \%$ & 2 & Baik \\
$0,5 \%<$ ROA $\leq 1,25 \%$ & 3 & Cukup \\
$0 \%<$ ROA $\leq 0,5 \%$ & 4 & Tidak Baik \\
ROA $\leq 0 \%$ & 5 & Sangat Tidak Baik \\
\hline
\end{tabular}

Sumber (PPBI, 2011)

Dividen merupakan kompensasi yang diterima oleh pemegang saham, di samping capital gain (Hanafi \& Halim, 2016, p.361). Oleh karena itu dividen ini merupakan bagian dari penghasilan yang diharapkan oleh pemegang saham. Besar kecilnya dividen yang dibayarkan akan mempengaruhi pencapaian maksimisasi kesejahteraan pemegang saham. Dividen payout ratio adalah perbandingan antara dividen yang dibayarkan dengan laba bersih yang didapatkan dan biasanya disajikan dalam bentuk persentase. Dividen payout ratio mengindikasikan jumlah dividen yang dibayar relatif terhadap earnings / hasil perusahaan (Titman et al., 2018, p.68). Semakin tinggi dividen payout ratio akan menguntungkan para investor tetapi dari pihak perusahaan akan memperlemah internal financial karena memperkecil laba ditahan. Sebaliknya dividen payout ratio semakin kecil akan merugikan para pemegang saham (investor) tetapi internal financial perusahaan semakin kuat. Rata-rata dividen payout ratio berkisar antara 0-5\%. DPR > 5\% terdapat kemungkinan dapat mengganggu likuiditas perusahaan, khususnya jika dividen yang dibagikan adalah dividen kas (Hadi, 2013, p.81).

Riset ini dikaji berdasarkan beberapa peneliti terdahulu yaitu: (i) Pengaruh Return On Asset, Debt To Equity Ratio, Collateral Asset, dan Pertumbuhan Aset Terhadap Kebijakan Dividen yang dilakukan di BEI melibatkan 29 perusahaan Manufaktur yang di BEI periode 2011-2013 dengan analisis regresi linier berganda. Hasil ini menunjukkan bahwa ROA dan Collateral Asset secara parsial berpengaruh positif dan signifikan terhadap Kebijakan Dividen dan Debt to Equity Ratio dan Pertumbuhan Aset tidak berpengaruh terhadap Kebijakan Dividen (Puspita Wati, 2015); (ii) Analisis Kepemilikan Manajerial, Kebijakan Hutang dan Profitabilitas Terhadap Kebijakan Dividen dan Nilai Perusahaan pada 13 Perusahaan Manufaktur yang Terdaftar di BEI periode 2018-2012 dengan teknik analisis jalur. Hasil ini menunjukkan bahwa kepemilikan manajerial berpengaruh signifikan terhadap kebijakan dividen sedangkan kebijakan hutang dan profitabilitas tidak berpengaruh signifikan terhadap kebijakan dividen. Profitabilitas berpengaruh signifikan terhadap nilai perusahaan sedangkan kepemilikan manajerial, kebijakan hutang dan kebijakan dividen tidak berpengaruh signifikan terhadap nilai perusahaan (Sumanti \& Mangantar, 2015); (iii) Pengaruh Rasio Keuangan dan 
Kepemilikan Institusional terhadap Dividend Policy pada sub sektor Konstruksi dan Bangunan yang listing di BEI menggunakan 11 perusahaan selama tahun 2011-2015 yang menghasilkan temuan yaitu rasio profitabilitas dan kepemilikan institusional berpengaruh positif sementara rasio utang tidak berpengaruh signifikan terhadap divident policy (Husain, 2016); (iv) Pengaruh CR, DER dan ROA Terhadap DPR pada Perusahaan Manufaktur di BEI dengan melibatkan 7 perusahaan dari 45 perusahaan yang terindeks LQ-45 dengan periode 2010-2015, dengan hasil yang menunjukan tidak ada pengaruh CR terhadap DPR, ada pengaruh DER dan ROA terhadap DPR dan secara simultan CR, DER, dan ROA berpengaruh terhadap DPR (Wahyuni \& Hafiz, 2018); dan (v) Faktor-Faktor Yang Mempengaruhi Kebijakan Dividen Pada Perusahaan Manufaktur Di Bursa Efek Indonesia dengan teknik purposive sampling sebanyak 9 perusahaan, teknik analisis menggunakan regresi linear berganda. Hasil analisis menunjukan bahwa profitabilitas, likuiditas, ukuran perusahaan berpengaruh positif dan signifikan terhadap kebijakan dividen sedangkan hasil analisis dari tingkat pertumbuhan pertumbuhan perusahaan berpengaruh negatif dan signifikan terhadap kebijakan dividen (Dewi \& Sedana, 2018). Dengan demikian, dapat dirumuskan secara spesifik kerangka penelitian berikut ini:

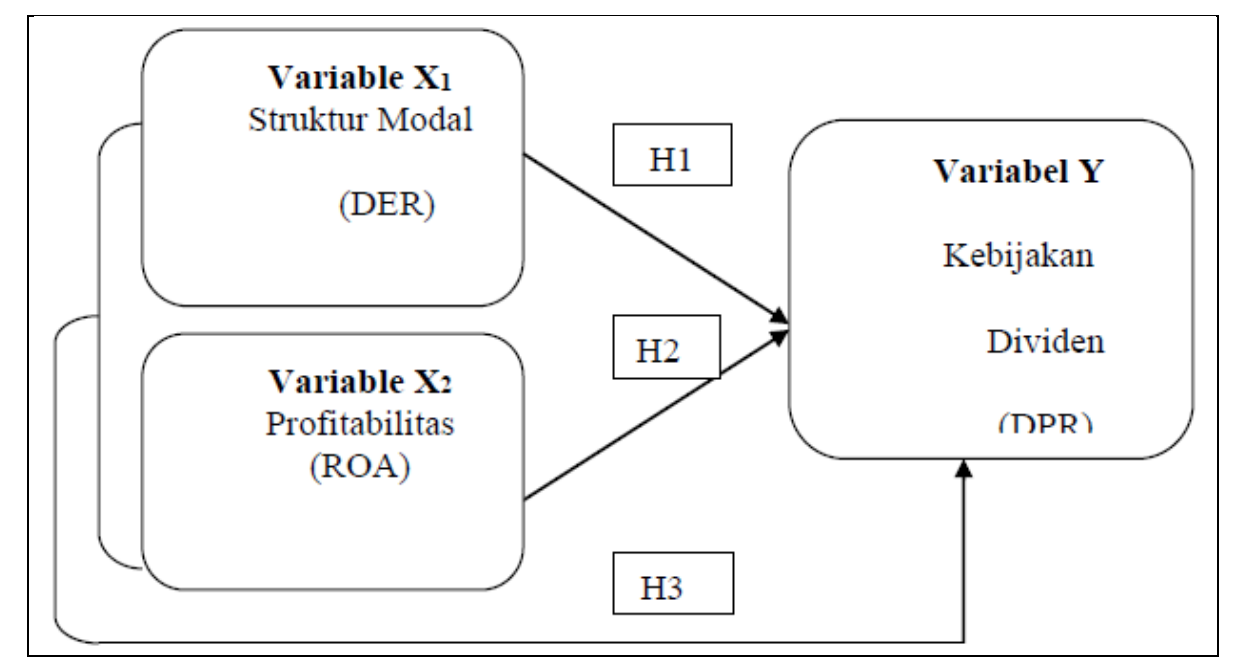

Gambar 1 Kerangka Penelitian

Hipotesis penelitian ini dirumuskan sebagai berikut:

$\mathrm{H}_{1}$, diduga adanya pengaruh Struktur Modal (DER) terhadap Kebijakan Dividen (DPR).

$\mathrm{H}_{2}$, diduga adanya pengaruh Profitabilitas (ROA) terhadap Kebijakan Dividen (DPR).

$\mathrm{H}_{3}$, diduga adanya pengaruh Struktur Modal (DER) dan Profitabilitas (ROA) secara simultan terhadap Kebijakan Dividen (DPR). 


\section{METODE PENELITIAN}

Jenis penelitian ini yaitu riset kausalitas yang merupakan karakteristik masalah berupa hubungan yang bersifat sebab akibat antara variabel independen (variabel yang mempengaruhi) dan dependen (dipengaruhi) (Sugiyono, 2018, hal. 62). Penelitian ini menggunakan pendekatan kuantitatif dimana merupakan serangkaian observasi atau pengukuran hasilnya menggunakan data sekunder yang berasal dari perpustakaan Bursa Efek Indonesia yang dapat diakses secara online melalui website www.idx.co.id berupa laporan keuangan. Populasi adalah wilayah yang digeneralisasi atas subyek atau obyek yang mempunyai kualitas dan karakteristik tertentu yang ditetapkan oleh peneliti untuk dipelajari dan kemudian ditarik kesimpulannya (Sugiyono, 2018, hal. 117). Pengambilan sampel dilakukan sebagai upaya untuk menetapkan bagian dari populasi, dengan mempertimbangkan representasi dari elemen populasi untuk memperoleh data dan informasi penelitian (Indrawati, 2015). Sumber data penelitian ini meliputi data sekunder yaitu data yang diperoleh dari Bursa Efek Indonesia yaitu PT. Mayora Indah, Tbk. yang berupa laporan neraca dan laporan laba rugi dari tahun 2011 sampai dengan tahun 2017 sehingga diperoleh informasi yang cukup untuk menggambarkan keadaan laporan keuangan. Metode analisis data adalah proses mencari dan menyusun secara sistematis data yang diperoleh dari hasil wawancara, catatan lapangan, dokumentasi, dan bahan-bahan lain, sehingga dapat mudah dipahami dan temuannya dapat di informasikan kepada orang lain (Sugiyono, 2018, p.244). Alat analisis menggunakan regresi linear berganda dengan bantuan program Statistical Package for Social Science (SPSS) Versi 24. Tahapan analisis data dilakukan antara lain: (i) analisis rasio keuangan melalui uji deskriptif statistik; (ii) uji asumsi klasik dengan normalitas, multikolinearitas, heteroskedastisitas dan uji autokorelasi; dan (iii) analisis regresi berganda dengan persamaan $\mathrm{Y}=\mathrm{a}+\mathrm{b}_{1} \mathrm{X}_{1}+\mathrm{b}_{2} \mathrm{X}_{2}+\mathrm{e}$; (iv) koefisien determinasi $\left(\mathrm{R}^{2}\right)$ untuk mengetahui seberapa besar kemampuan variabel independen menjelaskan variabel dependen; (v) uji Koefisien Regresi Secara Parsial (Uji t) dengan syarat apabila t hitung > t tabel maka variabel $\mathrm{X}$ secara parsial atau individual berpengaruh terhadap variabel $\mathrm{Y}$ atau sebaliknya; dan (vi) uji koefisien regresi secara simultan dengan syarat apabila $f$ hitung $>\mathrm{f}$ tabel atau menghasilkan probabilitas signifikansi kurang dari alpha 5 persen maka variabel $\mathrm{X}$ berpengaruh terhadap variabel $\mathrm{Y}$ atau sebaliknya. 


\section{HASIL PENELITIAN DAN PEMBAHASAN}

\section{Hasil Penelitian}

PT. Mayora Indah, Tbk. (selanjutnya disebut perusahaan) didirikan pada tanggal 17 Februari 1997. Perusahaan berdomisili di tangerang dengan pabrik berlokasi di Tangerang dan Bekasi. Kantor Pusat beralamat di Gedung Mayora 41 Group Headquarter, Jl. Daan Mogot KM.18 Cengkareng, Jakarta - 11840. Perusahaan mulai beroperasi secara komersil pada bulan Mei 1978. Perusahaan juga merupakan induk perusahaan baik secara langsung maupun tidak langsung memiliki lebih dari 50\% saham anak perusahaan yaitu PT. Sinar Pangan Barat (SPB) yang berdomisili di Medan, PT. Sinar pangan Timur (SPT) yang berdomisili di Surabaya, PT. Tora Bika Eka Semesta (TES) yang berdomisili di Tangerang, PT. Kakao Mas Gemilang (KMG), dimiliki TES dengan kepemilikan 96\% saham, berdomisili di Tangerang dan Mayora Nederland B.V., berdomisili di Belanda yang jenis usahanya jasa keuangan dan mulai beroperasi sejak tahun 1996. Saat ini perusahaan menjalankan bidang industri makanan olahan, antara lain biskuit, kembang gula, wafer, coklat dan jelly. Produk-produk perusahaan telah mendapat tempat yang baik di kalangan konsumen makanan ringan untuk menjangkau seluruh lapisan konsumen telah diciptakan berbagai macam produk dengan nama, kualitas, dan harga yang berbeda.
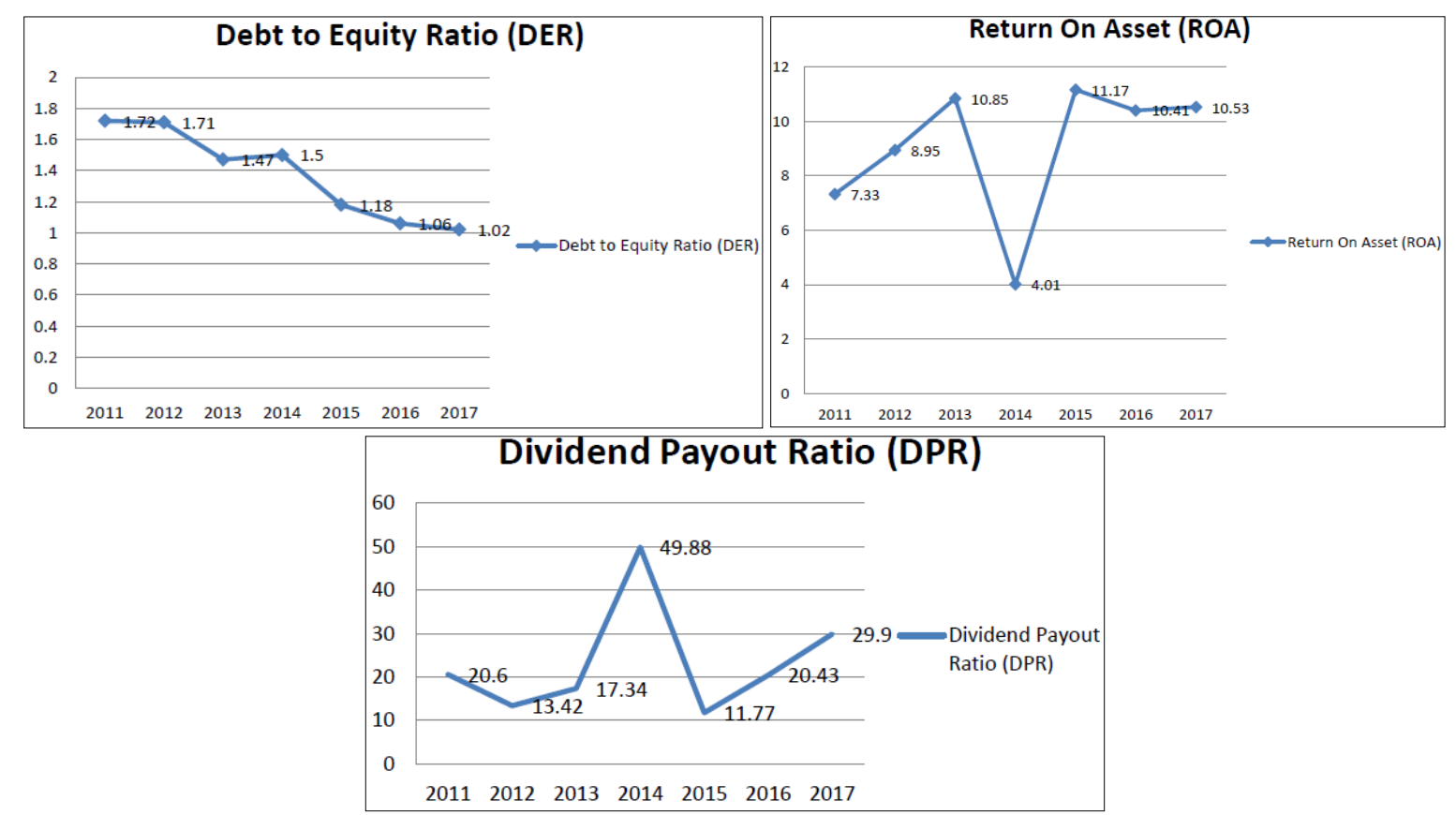

Gambar 2 Rasio DER, ROA dan DPR Tahun 2011-2017

Rasio DER dari tahun 2011 hingga tahun 2017 mengalami penurunan dari 1,72 kali hingga 1,02 kali sementara rasio ROA cukup fluktuatif mengalami peningkatan sejak tahun 2011 hingga tahun 2013 sebesar 10,85 persen, penurunan yang cukup signifikan di tahun 2014 
sebesar 4,01 persen dan meningkat di tahun 2015 hingga 2017 pada persentase di atas 10 persen. Rasio DPR pada tahun 2011 sekitar 20,6 persen mengalami penurunan dan peningkatan yang signifikan hingga tahun 2014 sebesar 49,88 persen kemudian mengalami penurunan di tahun 2015 sebesar 11,77 persen dan meningkat kembali hingga tahun 2017 sebesar 29,29 persen.

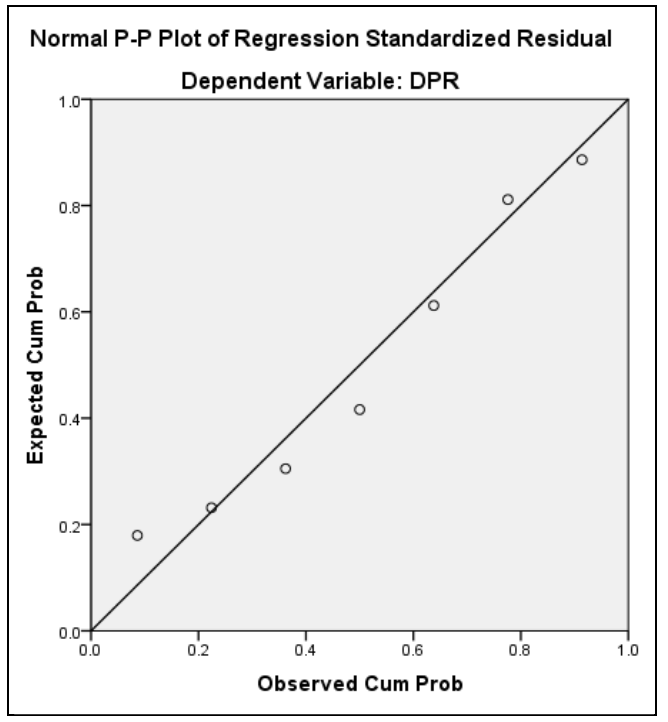

Gambar 3 Hasil Uji Normalitas: P-Plots

Hasil uji normalitas dengan teknik p-plots dapat disimpulkan bahwa titik-titik menyebar pada garis diagonal dan mengikuti arah garis diagonal. Hal ini menunjukan bahwa model regresi memenuhi asumsi normalitas.

Tabel 3 Hasil Uji Multikolinearitas

\begin{tabular}{ccc}
\hline Variebel & Nilai VIF & Nilai Tolerance \\
\hline Struktur Modal (X1) & 1,406 & 0,711 \\
Profitabilitas (X2) & 1,406 & 0,711 \\
\hline Sumber: Data diolah SPSS 24.00 (2019) &
\end{tabular}

Hasil uji multikolinearitas dapat dilihat bahwa nilai variance inflation factor (VIF) yang digunakan untuk kedua variabel independen ini berada di sekitar angka 1 dan kurang dari angka 10. Sementara itu, nilai tolerance yang didapatkan skor yang mendekati angka 1. Hal ini menunjukan bahwa model regresi dalam penelitian ini bebas multikolinearitas. 


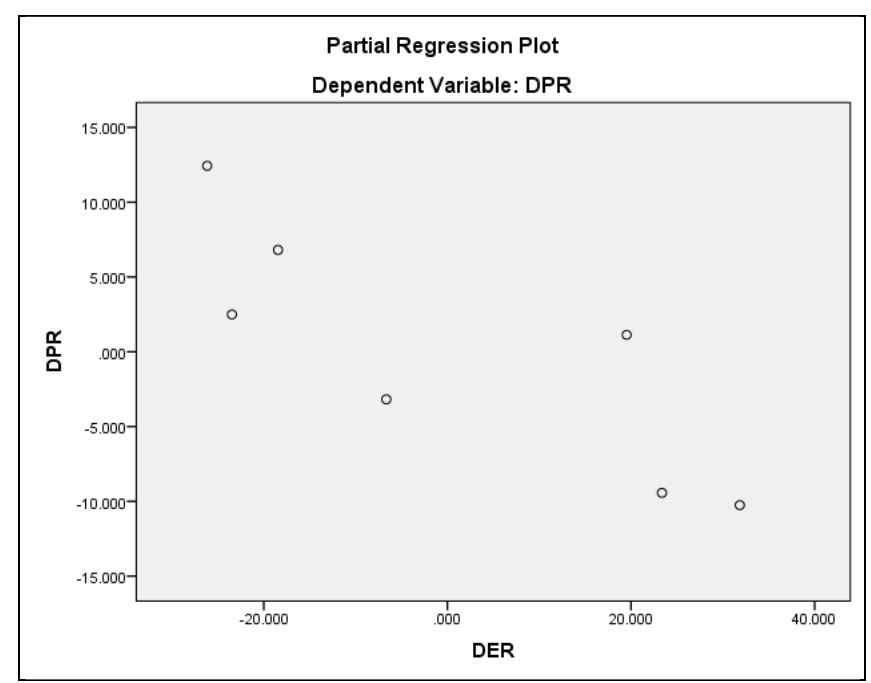

Gambar 4 Hasil Uji Heteroskedastisitas: Scatterplot

Hasil uji heteroskedastisitas dengan teknik scatterplot dapat disimpulkan terlihat titik-titik menyebar secara acak serta tersebar baik di atas maupun di bawah angka 0 pada sumbu Y. Hal ini menunjukkan tidak terjadi heteroskedastisitas pada model regresi.

Tabel 4 Hasil Uji Autokorelasi

\begin{tabular}{cc}
\hline $\mathrm{k}: 2, \mathrm{n}: 7$ & Skor \\
\hline $\mathrm{dL}$ & 0,294 \\
$\mathrm{dU}$ & 1,676 \\
$\mathrm{dW}$ & 1,760 \\
\hline \multicolumn{2}{l}{ Sumber: Data diolah SPSS $24.00(2019)$}
\end{tabular}

Angka dW menghasilkan 1,760 untuk pengujian autokorelasi, dengan jumlah variabel independen (k) sebanyak 2 (dua) dan jumlah sampel (n). Berdasarkan kriteria yang telah ditentukan, untuk jumlah sampel sebesar 7 (tujuh) maka tidak dapat mengidentifikasi nilai dL maupun dU karena hanya terdiri dari 1 (satu) perusahaan yaitu PT. Mayora Indah, Tbk.

Tabel 5 Rangkuman Hasil Uji Koefisien Determinasi $\left(\mathrm{R}^{2}\right)$

\begin{tabular}{lcccc}
\hline Model & $\mathbf{R}$ & $\mathbf{R}^{\mathbf{2}}$ & Adjusted $\mathbf{R}^{\mathbf{2}}$ & SE of the Estimate \\
\hline 1 & $0,938^{\mathrm{a}}$ & 0,879 & 0,819 & 5,58635 \\
\hline
\end{tabular}

Nilai koefisien determinasi $\left(\mathrm{R}^{2}\right)$ diperoleh sebesar 0,879 , artinya 87,9 persen perubahan dari variabel Struktur Modal (X1) dan Profitabilitas (X2) dijelaskan oleh variasi variabel Kebijakan Dividen (Y), sisanya 12,1 persen dijelaskan oleh variabel lain yang tidak diteliti.

Tabel 6 Rangkuman Hasil Uji ANOVA

\begin{tabular}{lccc}
\hline Model & df & F & Sig. \\
\hline 1 & 2,4 & 14,529 & $0,015^{\mathrm{b}}$ \\
\hline
\end{tabular}


Nilai F-hitung diketahui sebesar 14,529 dengan signifikansi 0,01 (lebih kecil dari alpha 5\%), sehingga menolak $\mathrm{H}_{0}$. Variabel Struktur Modal (X1) dan Profitabilitas (X2) secara simultan berpengaruh terhadap variabel Kebijakan Dividen (Y).

Tabel 7 Rangkuman Hasil Uji t

\begin{tabular}{lccc}
\hline Model & B & t & Sig. \\
\hline (Constant $)$ & 112,764 & 5,758 & 0,005 \\
X1 & $-27,923$ & $-3,037$ & 0,039 \\
X2 & $-5,633$ & $-5,388$ & 0,006 \\
\hline
\end{tabular}

Hasil dari uji parsial dituangkan dengan hasil persamaan regresi berganda sebagai berikut:

\begin{tabular}{|c|c|}
\hline $\mathrm{Y}$ & $=112,764-27,923 \mathrm{X} 1-5,633 \mathrm{X} 2+\mathrm{è}$ \\
\hline & $\begin{array}{l}\text { : } 112,764 \text {. Artinya rata-rata kontribusi variabel independen selain } \mathrm{X} 1 \\
\text { dan } \mathrm{X} 2 \text { juga memberikan dampak positif terhadap nilai } \mathrm{Y} \text {. }\end{array}$ \\
\hline $\mathrm{X} 1$ & $\begin{array}{l}\text { : -27,923. Artinya X1 memiliki pengaruh negatif terhadap Y, jika } \\
\text { terjadi kenaikan X1 sebesar } 1 \text { (satu) kali dan variabel independen } \\
\text { lainnya bernilai tetap, maka Y akan mengalami penurunan sebesar } 1 \text {. }\end{array}$ \\
\hline $\mathrm{X} 2$ & $\begin{array}{l}\text { : -5,633. Artinya X2 memiliki pengaruh positif terhadap Y, jika terjadi } \\
\text { kenaikan X2 sebesar } 1 \text { (satu) kali dan variabel independen lainnya } \\
\text { bernilai tetap, maka Y akan mengalami penurunan sebesar } 1 .\end{array}$ \\
\hline
\end{tabular}

\section{Pembahasan}

Struktur Modal (X1) dengan proksi Debt-to Equity Ratio (DER) memiliki pengaruh terhadap Kebijakan Dividen (Y) dengan probabilitas signifikansi sebesar 0,039 (kurang dari alpha 5 persen), temuan hasil ini sejalan dengan penelitian yang membuktikan pengaruh DER terhadap kebijakan dividen (Wahyuni \& Hafiz, 2018) sementara bertolak belakang dengan hasil yang tidak membuktikannya terhadap kebijakan dividen (Puspita Wati, 2015; Sumanti \& Mangantar, 2015; Husain, 2016). Leverage menggambarkan kemampuan pembiayaan perusahaan yang bersumber dari pihak ketiga. Leverage PT. Mayora Indah, Tbk. menjadi faktor penentu dalam menentukan kebijakan dividen perusahaan, hal ini disebabkan kreditur yang menjadi pihak berkepentingan sebagai sumber pendanaan perusahaan juga mengawasi dengan ketat dan mensyaratkan ketentuan-ketentuan yang terkait dengan pinjaman perusahaan.

Profitabilitas (X2) dengan proksi Return On Assets (ROA) memiliki pengaruh terhadap Kebijakan Dividen (Y) dengan probabilitas signifikansi sebesar 0,006 (kurang dari alpha 5 persen), temuan hasil ini sejalan dengan semua penelitian terdahulu yang membuktikan 
pengaruh ROA terhadap kebijakan dividen (Puspita Wati, 2015; Sumanti \& Mangantar, 2015; Husain, 2016; Wahyuni \& Hafiz, 2018; Dewi \& Sedana, 2018). Besarnya profitabilitas perusahaan yang diperoleh dari tingkat pengembalian aset perusahaan menjamin akan selalu menentukan kebijakan terkait dengan pembayaran dividen yang tinggi kepada shareholders' Struktur Modal dan Profitabilitas secara simultan memiliki pengaruh terhadap Kebijakan Dividen (Y) dengan probabilitas signifikansi sebesar 0,015 (kurang dari alpha 5 persen), temuan hasil ini sejalan dengan penelitian yang membuktikan pengaruh simultan faktor yang melibatkan DER dan ROA terhadap kebijakan dividen (Puspita Wati, 2015; Wahyuni \& Hafiz, 2018) sementara tidak membuktikan pengaruh simultan (Husain, 2016).

\section{KESIMPULAN DAN IMPLIKASI}

Kesimpulan penelitian ini adalah Struktur Modal dan Profitabilitas baik secara simultan maupun parsial berpengaruh terhadap Kebijakan Dividen Pasien. Investor dapat menentukan portfolio investasi ke dalam bentuk saham PT. Mayora Indah, Tbk. dan menginvestasikan kembali dividen yang dibagikan dalam kepemilikan perusahaan. Sementara OJK dapat mengevaluasi dan merumuskan kembali kebijakan terkait dengan dividend payout ratio khususnya untuk perusahaan yang listing di BEI. Hasil penelitian ini juga diharapkan dapat memberikan kontribusi dalam pengembangan teori, terutama dalam bidang manajemen keuangan mengenai pengaruh struktur modal dan profitabiltias terhadap kebijakan dividen dan dapat digunakan sebagai acuan untuk penelitian mendatang menggunakan proksi lainnya.

\section{DAFTAR PUSTAKA}

Dewi, I.A.P.P. \& Sedana, I.B.P., 2018. Faktor-Faktor Yang Mempengaruhi Kebijakan Dividen Pada Perusahaan Manufaktur Di Bursa Efek Indonesia. E-Jurnal Manajemen Unud, 7(7), pp.3623-52.

Ginting, S. \& Tarihoran, A., 2017. Faktor-Faktor Yang Mempengaruhi Pernyataan Going Concern. Jurnal Wira Ekonomi Mikroskil, 7(01).

Hadi, N., 2013. Pasar Modal. 1st ed. Yogyakarta: Graha Ilmu.

Hanafi, M.M. \& Halim, A., 2016. Analisis Laporan Keuangan. Yogyakarta: UPP STIM YKPN.

Harahap, S.S., 2009. Analisis Kritis Atas Laporan Keuangan. Jakarta: Raja Grafindo Persada. Horne, J.C.V. \& Wachowicz, J..J.M., 2012. Prinsip-Prinsip Manajemen Keuangan (Fundamentals of Financial Management), Buku 1. 13th ed. Jakarrta: Salemba Empat.

Husain, T., 2016. Pengaruh Rasio Keuangan dan Kepemilikan Institusional terhadap Dividend Policy (Studi Empiris pada Perusahaan Sub Sektor Konstruksi dan Bangunan yang Terdaftar di Bursa Efek Indonesia Periode Tahun 2011-2015). MABISKA Journal, 1(1), pp.56-72. 
Indrawati, 2015. Metode Penelitian Manajemen dan Bisnis Konvergensi Teknologi Komunikasi dan Informatika. Bandung: PT.Refika Aditama.

Kasmir, D., 2016. Analisis Laporan Keuangan. Jakarta: PT. Rajagrafindo Persada. Martono \& Harjito, A., 2010. Manajemen Keuangan. 3rd ed. Yogyakarta: Ekonisia.

Murtini, U., 2018. Pengaruh Enterprise Risk Management Terhadap Nilai Perusahaan Dengan Variabel Kontrol: Ukuran Perusahaan dan DER. Jurnal Bisnis, Manajemen \& Perbankan (JBMP), 4(1), pp.77-94.

Nasution, Y.S.J., 2015. Peranan Pasar Modal Dalam Perekonomian Negara. HUMAN FALAH, 2(1), pp.95-112.

PPBI, 2011. Peraturan Bank Indonesia Nomor 13/1/PBI/2011 tentang Penilaian Tingkat Kesehatan Bank Umum. Jakarta: Bank Indonesia.

Puspita Wati, T.A., 2015. Pengaruh Return On Asset, Dept To Equity Ratio, Collateral Asset, dan Pertumbuhan Aset Terhadap Kebijakan Dividen. [Online] FE Universitas Negeri Yogyakarta (Online) Available at: https://eprints.uny.ac.id/19098/1/TikaAyuPuspitawati 11408141039.pdf [Accessed 25 Januari 2020].

Rahayu, M. \& Sari, B., 2018. Faktor-Faktor Yang Mempengaruhi Nilai Perusahaan. IKRAITH-HUMANIORA, 2(2), pp.69-76.

Sugiyono, 2018. Metode Penelitian Evaluasi: Pendekatan Kuantitatif, Kualitatif, dan Kombinasi. Bandung: CV. Alfabeta.

Sumanti, J.C. \& Mangantar, M., 2015. Analisis Kepemilikan Manajerial, Kebijakan Hutang dan Profitabilitas Terhadap Kebijakan Dividen dan Nilai Perusahaan Pada Perusahaan Manufaktur yang Terdaftar di BEI. Jurnal EMBA, 3(1), pp.1141-51.

Titman, S., Keown, A.J. \& Martin, J.D., 2018. Financial Management: Principles and Applications. Boston: Prentice Hall.

Trisna Dewi, N.W. \& Panji Sedana, I.B., 2014. Pengaruh Struktur Modal, Likuiditas dan Pertumbuhan terhadap Kebijakan Dividen di BEI. E-Jurnal Manajemen, 3(6), pp.1739-52.

Wahyuni, S.F. \& Hafiz, M.S., 2018. Pengaruh CR, DER dan ROA Terhadap DPR pada Perusahaan Manufaktur di BEI. Jesya (Jurnal Ekonomi \& Ekonomi Syariah), 1(2), pp.25-42. 